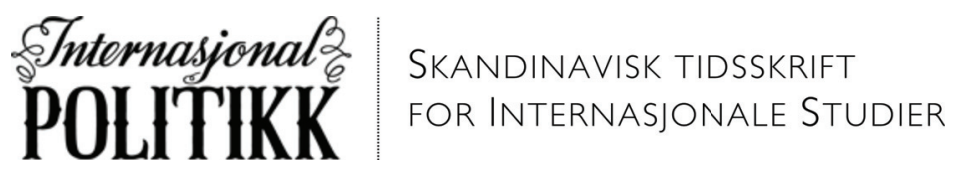

Årgang 75, Nummer 1, side 36-44, 2017, ISSN 1891-5580, www.tidsskriftet-ip.no, Publisert mars 2017

FoKUS: SKANDINAVIA OG USA

\title{
USA og Norge i Trumps verden
}

\author{
Anders G. Romarheim \\ Institutt for forsvarsstudier
}

Hva kjennetegner forholdet mellom Norge og USA? Vi befinner oss på hver vår side av Nord-Atlanteren. I noen saker er det et osean av forskjell mellom Norge og USAs posisjoner, men det er også mange ting som binder oss sammen. De historiske folkelige båndene er sterke, drevet fram av utvandringen på 1800-tallet. Vi nordmenn er egentlig diasporaen ettersom nordmenn og norskamerikanere er omtrent jevnstore folkegrupper. Samtidig finner vi de sterkeste mellomstatlige bånd nettopp i det sikkerhetspolitiske og ideologiske samholdet som har oppstått rundt et felles hav.

I tillegg til å dele og overvåke store havområder, deler USA og sjøfartsnasjonen Norge skjebnefellesskap forankret i NATO-paktens artikkel V. Dette er forsvarspaktens utløsende klausul, og slår fast at et militært angrep på ett NATO-land anses som en krigserklæring mot hele alliansen. Det trigger kollektivt forsvar. Hvordan har forholdet til vår nærmeste allierte vært? Hva innebærer dette samarbeidet når det gjelder diplomati og etterretning? Hva betyr det kulturelt og sikkerhetspolitisk? Og sist men ikke minst: vil de historisk sterke båndene svekkes nå som Donald Trump har inntatt Det hvite hus?

USA og Norge innehar noen felles nasjonale særtrekk. Fremfor alt gjelder dette en langt fremskreden selvopptatthet. Nordmenn er besatt av Norge og alt norsk. Amerikanere flest forguder Amerika og selve ideen USA. Begge nasjoner er eksepsjonalister som dyrker en tro på at nettopp vi har en særegen rolle å spille i verden, som ingen andre kan ivareta like godt. ${ }^{1}$ I Norge betones dette i munnhell om at "Gud er norsk, og det er typisk norsk å være god». USA har på sin side en fastsatt skjebne manifest destiny - til å dominere på sitt eget kontinent og hemisfære, samt instituere en

\footnotetext{
${ }^{1}$ Se Hilde Restad (2014) for en definisjon og diskusjon av amerikansk eksepsjonalisme. 
godartet vestlig liberal verdensorden. Denne ordenen har blitt ivaretatt av presidenter fra begge partier.

Som Robert Jervis (2017) skriver får vi med Trump en lakmustest på hvor mye «the personality and political preferences of the leader affects the state's foreign policy». Stephen Walt (2017) påpeker på sin side at forutsetningen om rasjonelle aktører i utenrikspolitikkens utforming vil bli satt på prøve med Trump i Det hvite hus. Dersom man legger de første ukene og handlingene til President Trump til grunn ser det ut til at presidenten med noen pennestrøk vil erstatte bredt forankrede amerikanske utenrikspolitiske tradisjoner med opp mot irrasjonell og unødvendig konfronterende politikk.

USA er som Bill Clinton og hans administrasjon uttrykte det: The indispensable Nation. USA er en supermakt med innflytelse, interesser, allierte og utfordrere i alle klodens kriker og kroker. Vil man realisere et konkret utfall i internasjonal politikk, er det nesten alltid en ulempe om USA er imot. Norge er etter egne sigende en humanitær stormakt og global altruist, som kan skape fred og forsoning selv mellom Kain og Abel. Vi gir alltid mer per kapita til gode formål enn alle andre, og klapper oss selvtilfredse på skulderen over det. ${ }^{2}$ Vi er gode. En kraft for det gode. På samme måte anser USA sitt lederskap i verden for å være et gode, også for verden. USA er den lysende byen på høydedraget som leder, inspirerer og opplyser resten av verden. ${ }^{3}$ Hvordan forholder lille Norge seg til et slikt land?

\section{Sikkerhetspolitikk: likheter og forskjeller}

Vårt bilaterale samarbeid har gått på tvers av de fleste samfunnssektorer og reflektert sammenfallende interesser og verdier. Demokratisk styreform, kollektivt forsvar, samt stabile maktforhold langs respekterte grenser i våre nærområder står sentralt. Videre er suverenitet og statens videre eksistens på toppen i hierarkiet av sikkerhetspolitiske interesser. Nettopp av den grunn treffer Russlands nylige cyber-innblanding i USAs presidentvalg så forkjært (Lipton, Sanger \& Shane 2016). Det rokker ved styresettet, handlingsfriheten og suvereniteten. Forsøk på å påvirke og manipulere USAs demokratiske valg - selve retten til å velge sine egne ledere - er en suverenitetskrenkelse, om enn av ikke-territoriell karakter. At USA mangfoldige ganger har søkt å påvirke hvem som har makten $i$ andre land går USA forbi i stillhet ved denne anledning.

Utfordringer har det også vært mellom USA og Norge opp igjennom. Selv om enigheten på det sikkerhetspolitiske felt langt overstiger uenighetene har historiske rifter inntruffet. Dette gjelder særlig etter avviklingen av den kalde krigen da mulighetsrommet økte for å utforme norsk utenrikspolitikk utenom en fastlåst bipolær struktur mellom NATO og Warszawapakten. Den utenrikspolitiske konsensus som kjennetegnet den kalde krigen myknet opp.

\footnotetext{
${ }^{2}$ Se Leira et al. (2007) og Tvedt (2009) for en diskusjon av norske selvbilder i utenrikspolitikken. ${ }^{3}$ Frasen 'city upon a hill' benyttes ofte i referanse til USAs evne til å lede verden gjennom å sette et inspirerende eksempel (Se Beasley 2004: 30, 47). Frasen er en gjenganger i 'presidential rhetoric', og har vært omfavnet og artikulert av blant andre Barack Obama, Ronald Reagan og John F. Kennedy.
} 
På slutten av 90-tallet var USA og Norge uenige om å innskrenke eller forby bruken av anti-personell landminer. Saken skapte også rifter internt i Norge da Utenriksdepartementet (UD) var aktive internasjonalt i saken, mens en mer rendyrket sikkerhetspolitisk NATO-linje gjorde seg gjeldende gjennom Forsvarsdepartementet (FD). USA truet med å trekke tilbake sitt forhåndslagrede militære utstyr og dermed bøyde Norge av, i alle fall midlertidig. ${ }^{4}$ Men tiden jobbet for Norge, og det ble etter hvert en slags stilltiende aksept mellom Jonas Gahr Støre og Condoleezza Rice for at Norge bidro i saken. Tilsvarende interne rifter har inntruffet rundt flere såkalte 'humanitære nedrustningssaker' der Norge og USA kan ha ulike interesser, og sakene betraktes ulikt av UD og FD.

På 2000-tallet var det også uenigheter mellom Norge og USA. Tre av de vanskeligste sakene var Irak-krigen, utviklingen av et rakettskjold i Europa og anerkjennelse av Hamas som lovlig valgt styresmakt i palestinske områder. Motstanden mot Irak-krigen var bred internasjonalt, så der svømte vi trygt i stim med Tyskland og Frankrike i spissen. Når det gjaldt å anerkjenne Hamas var Norge derimot alene og i første rekke og provoserte derfor USA ekstra. Selv om en del vil hevde at anerkjennelse var riktig, var timingen feil. Norges anerkjennelse fremsto som overilt og måtte trekkes. Rakettskjolddebatten var intens for 10 år siden og har på ny blusset opp som en betent politisk sak der det er avgiørende å balansere amerikanske ønsker med norske behov.

Det er som sagt mer som forener Norge og USA enn som støter oss fra hverandre. Blant verdiene som forener oss er en dedikasjon til demokrati, rettstaten, fri og rettferdig handel, en global verdibasert engasjementspolitikk og i noen grad menneskerettigheter. Sistnevnte vektlegges i begge leire, men USA og Norge har ulik forståelse av hva det vil si å forfekte menneskerettigheter internasjonalt. Et felles trekk er dog at begge stater veier hensynet til menneskerettighetene opp mot handelspolitiske og sikkerhetspolitiske interesser.

\section{Trump - Fra TV-stjerne til President}

Vi har så langt beskjeftiget oss med det bilaterale forholdet langs de diplomatiske og kulturelle aksene og på forsvarspolitisk samarbeid pre-Trump. Hvordan vil dette utarte når Trump entrer scenen? Det må slås fast at å spå om fremtidig politikk er alltid krevende. Ettersom Trump fremstår som uforutsigbarheten selv, blir det ekstra krevende. Men vi vet imidlertid en del om hvem Trump er, hva slags politiker han er og hvilken utenrikspolitikk han akter å føre. Legger vi til hans mange kontroversielle handlinger i de første ukene etter innsettelsen kan vi giøre noen kvalifiserte antakelser om hvordan Trumps presidentskap vil påvirke global strategisk stabilitet og orden.

Trump er like mye et fenomen som politiker. Han er nærmest en mytisk TV-skikkelse som har preget amerikansk samfunnsliv i en mannsalder. Enten det har vært missekonkurranser, fribryting, reality TV-show, eller oppkjøp og konkursgang, har Trump alltid stukket den særegne manken sin fram i rampelyset. Trump er

\footnotetext{
${ }^{4}$ Dette dokumenteres hos Tamnes, Rolf et al. (2004: 153), og hos Heier, Tormod (2005: 64).
} 
hyperkjendis i USA og fremstår som kjendisenes fyrste når han leder sitt TV-show Celebrity Apprentice. Her har et bredt spekter av USAs kjendiser krøpet for Trump, og grått sine bitre tårer, når han har misbilliget dem og til sist strakt pekefingeren mot dem og utbasunert: You're Fired!

De siste ti årene har han også blitt en fast «innringer» til Fox News sine politiske talkshow. Det er her han startet oppbyggingen av sin politiske plattform. Trump var en mer moderat Demokratisk-lenende person tidligere, men gjennom Fox News har han redefinert seg som politiker med konservativ appell. Helomvendingen i abortspørsmålet er den tydeligste posisjoneringen han har gjennomført for å bli en spiselig kandidat i det republikanske primærvalget. Omfavnelsen av privat våpenhold og det andre grunnlovstillegget har også definert Trump som en konservativ kandidat, også dette på tvers av tidligere posisjoner (Beckett \& Jacobs 2016).

Som person fremstår Trump som en alfahannenes alfahann som ikke frykter noe eller noen. Han betaler ikke skatt, han trår Kina på tærne, han fornærmer sin forgjenger og politikerne i Washington, samt utenlandske statsledere. Han fremstår tidvis som et rovdyr på toppen av næringskjeden som ikke kjenner noen eksistensielle trusler, og dermed aldri bøyer av eller frykter represalier. Han driver politikk som om motkrefter ikke finnes. Trump har en særegen populistisk stil som skiller han fra de fleste andre politikere. Han er brå og enormt hevngjerrig. Selv den minste negative tweet kan trigge et bombardement av smålige personangrep i retur. Han refererer til seg selv som en 'counter-puncher'. Den egenkarakteristikken er meget presis.

Trumps kone, Melania, holdt seg mye i bakgrunnen i valgkampen, men de få gangene hun introduserte ham var det gjerne som 'the greatest dealmaker'. Han er familiens overhode og vil trekke mye på familien og kanskje spesielt datteren Ivanka Trump når han nå etablerer et Trump-dynasti. En av hennes kanaler til innflytelse er gjennom ektemannen Jared Kushner som får en utenrikspolitisk rolle i Det hvite hus. Ivanka flytter til Washington DC og skal visstnok prioritere å følge opp barna, men hun vil trolig ha betydelig innflytelse på politikken til Trump. Melania blir boende i New York og gir dermed Ivanka rom til å redefinere rollen som førstedatter. Hun var synlig til stede da Trump møtte Japans statsminister Abe, Trumps første møte med en statsleder etter valgseieren.

Trump (1987) har utgitt boka The art of the Deal. Tittelen understreker et helt sentralt trekk for hva vi kan forvente av Trump i utenrikspolitikken. Trump fører en «transaksjonell» handelsorientert utenrikspolitikk og anser alt som mulig å reforhandle. Han har allerede signert et memorandum som vil trekke USA fra frihandelsavtalen TPP (Trans-Pacific Partnership) mellom 13 land på hver side av Stillehavet. Hvis ikke NATO-landene dekker sine egne forsvarsbehov kan sågar Atlanterhavspakten i ytterste konsekvens oppheves. Dette er naturligvis ikke særlig sannsynlig, og vil ikke skje så lenge General Mattis er forsvarsminister. Men mye tyder på at Trump betrakter internasjonal politikk som en kontinuerlig strøm av (re)forhandlinger der ingenting ligger fast og intet er forutsigbart eller endelig. Dette gjelder også allianser, avtaler og diplomatiske normer og konvensjoner.

Som politiker bedyrer Trump viktigheten av uforutsigbarhet, både innenriks, utenriks og i valgkamp. Tidlig i primærvalget nektet Trump å forplikte seg til å 
støtte den republikanske kandidaten uansett hvem det ble. Denne trusselen om et uavhengig kandidatur var et snedig trekk. Hele partiet visste at demokratene ville vinne om Trump stilte som uavhengig tredje kandidat og splittet den republikanske velgermassen. På samme vis sådde han tvil om han ville akseptere et valgnederlag for Hillary Clinton: 'I'll keep you in suspense', sa han den gang. Nettopp denne uforutsigbarheten og motviljen mot å forplikte seg til noe som helst, er noe av det skumleste med Trumps presidentskap internasjonalt. Troverdige forpliktelser skaper sikkerhet. Mangelen på forpliktelser og åpenhet om intensjoner skaper usikkerhet.

Internasjonal politikk utspiller seg $\mathrm{i}$ en anarkisk struktur uten noen effektiv rettstat eller andre overordnede suverene instanser. ${ }^{5}$ Dermed blir avtalene mellom nasjonalstatene og avklaring av maktforhold helt avgjørende for statenes utforming av sikkerhetspolitikk og interesser. Disse avtalene utgiør fundamentet for internasjonal politikk og styrer forventningene og etablerer og konstruerer statenes identiteter $\mathrm{i}$ forhold til hverandre. Når supermaktene, de største brikkene $\mathrm{i}$ dette spillet, er i konstant bevegelse blir hele systemet ustabilt og statenes søken etter sikkerhet kompliseres drastisk.

\section{Med Trump ved roret}

Som motvekt mot ustabilitet og potensielt kaos har USA stått som garantist for en liberal verdensorden. Med Trump ved roret sier ikke USA bare ifra seg denne rollen. Signalene så langt tilsier at Trump aktivt vil spre usikkerhet rundt egne intensjoner og forpliktelser, altså en form for systemrevisjonistisk adferd som bryter med lange utenrikspolitiske tradisjoner i USA. Slik tenkning har dog røtter innen den hardtslående og populistiske Jacksonian-tradisjonen (Mead 2003; Mead 2017). ${ }^{6}$ Trump vil for eksempel ikke si hvilken strategi han vil benytte overfor ISIL, for da vet jo ISIL hva som kommer. Dette viser en vilje til å velge ukonvensjonelt, men samtidig en begrenset forståelse for hva hemmelighold rundt egen strategi kan utrette i en åpen militær konflikt, der også allierte må innvies i planene.

Informasjonsutveksling er en bærebjelke i bilaterale forhold. Mellom USA og Norge har utveksling av etterretningsinformasjon stått sentralt. Etterretningssamarbeid blir ofte trukket fram som spesielt viktig på toppmøter mellom USA og Norge. Havområdene og grensen til Russland i nord gir Norge en fremskutt geografisk plassering for å følge med på det russiske militærets manøvre og operasjonsmønstre. På dette feltet er Norge NATO-alliansens stor-grossist og strategisk viktig.

Etterretningssamarbeidet lever sitt eget avsondrede liv, litt på tvers av de øvrige bilaterale forbindelsene og toppnivået. Forbindelsene forble stabile gjennom hele Bush-perioden og består nok også under Trump. Men vil betydningen av tett

\footnotetext{
${ }^{5}$ Denne forutsetningen er spesielt viktig for realismens perspektiver på internasjonal poltikk. Imidlertid deler en del konstruktivister anarki-forutsetningen. Men perspektivene skiller lag i implikasjonene anarkiet har for staters adferd i internasjonal politikk. Som A. Wendt (1992) skriver: Anarchy is what states makes of it.

${ }^{6}$ For en grunnleggende gjennomgang av amerikanske utenrikspolitiske tradisjoner se Walter Russell Mead (2003) Special Providence.
} 
etterretningssamarbeid svekkes dersom Trump er lite opptatt av sitt eget gigantiske nasjonale etterretningsapparat? Før innsettelsen var han $\mathrm{i}$ åpen ordkrig med det amerikanske etterretningsmiljøet. Igjen ble riftene trigget av russisk hacking som forstyrret valgkampen og Trumps hvetebrødsdager. Rapportene om at han ønsker å høre mindre fra etterretningstjenestene og ikke har satt av tid til deres briefer i overgangsfasen bekymrer mange. Hvor får han da verdensbildet sitt fra? $\mathrm{Og}$ vil Norges stilling marginaliseres som konsekvens?

Det gode bilaterale forholdet har overlevd mye. Selv når kontroversielle George W. Bush satt i Det hvite hus og de rødgrønne, med Sosialistisk venstreparti, hadde regjeringsmakt gikk det forbausende bra. Den partipolitiske sammensettingen kunne knapt blitt mer krevende for det bilaterale forholdet. Anti-Nato-partiet SV programfestet at det republikanskledete USA var en trussel mot internasjonal fred og sikkerhet. Samtidig satt den mest profilerte USA-ambassadøren Norge har hatt på lang tid. Ambassadør Benson K. Whitney bidro til Bush sin valgseier i norsk-amerikanismens høyborg: Minnesota. Med et krevende utgangspunkt som Bush-lojalist maktet allikevel Whitney å skape et sterkt engasjement med Norge og nordmenn gjennom USAs offentlige diplomati.

Kontrasten er stor til Obama-perioden. Selv SV-topper som Erik Solheim bejublet Obamas valg, men vi opplevde deretter et diplomatisk vakuum uten ambassadør til Norge. Da Obama omsider utpekte en mann, så foreslo han en av de svakeste ambassadørkandidatene i manns minne. Det ble politisk blodbad i senatet der en uinformert George Tsunis tok til orde for et oppgjør med Fremskrittspartiets tankegods. Senator John McCain påpekte opprørt at Frp faktisk satt i regjering. Utpekingen var en ydmykelse overfor Norge. Det illustrerte det vi alle vet, men som vi hater å bli minnet om: USA er veldig viktige for oss, men vi er ikke særskilt viktige for USA. Tsunis trakk til slutt sitt uskikkede kandidatur.

Å predikere hvordan presidenter vil styre er krevende. Vi må ikke glemme at George W. Bush gikk til valg på en avmålt Bakeresque 'no-nation-building' realistisk utenrikspolitikk. Han skulle styre på samme vis som sin far, men slik gikk det på ingen måte etter at tvillingtårnene falt. Det er oftest hendelsene, og særlige krisene internasjonalt, som bestemmer hvilke saker og regioner som dominerer en presidents utenrikspolitikk. Obamas dreining mot Asia (pivot to Asia) var jo like mye et utenrikspolitisk program og visjon som en praktisk ført utenrikspolitikk.

Det er krisene i Europa og Midtøsten som har definert Obamas utenrikspolitiske agenda og ettermæle, nærmere bestemt Syria, Irak, Libya og Ukraina. Disse krisene overskygget hans utenrikspolitiske agenda og ønsker om langsiktig balansering av kinesisk innflytelse i Asia. Trumps skroting av handelsavtalen TPP er med på å forkaste Obamas handelspolitiske reisverk i Asia. Walt (2017) påpeker imidlertid at Trump ikke kan balansere Kina i Asia på egenhånd. Det bekymrer allikevel Trump og hans Jacksonianske velgere lite. De gjør opprør mot både Kina og en «global cosmopolitan ideology», uansett kostnadene (Mead 2017).

Vi har sett flere indikasjoner på at Trump ønsker å definere sin egen utenrikspolitikk på tvers av krisene. Det uvanlige er dog at Trump foreløpig ser ut til å designe krisene selv. Han provoserer og utfordrer Kina unødig. Den kalkulerte telefonsamtalen med 


\section{Anders G. Romarheim}

Taiwans president understreket dette ettertrykkelig. Utnevnelsen av Peter Navarro til en handelspolitisk toppstilling bærer bud om voldsom konfrontasjon med Kina, med bakgrunn i handelsrifter (Davidson 2016). Navarros krigerske boktitler taler for seg. ${ }^{7}$ Hvis Trump i tillegg flytter USAs Tel Aviv-ambassade til Jerusalem vil han sette sinnene i kok blant så vel fiender som allierte i den arabiske verden.

Trump er en fersk politiker og en nybakt president, mens Putin med lang fartstid har tatt imot nye amerikanske presidenter ved to anledninger. Her er det noen interessante mønstre som passer inn i den pågående oppmykningen mellom Kreml og Det hvite hus. Putin evnet fra starten av å innynde seg hos både Obama og George W. Bush. Sistnevnte sa at han tidlig så inn i Putins sjel og mente de to delte en dyp, gjensidig forståelse. Forståelsen var nok ufullkommen og kanskje ensidig. På slutten av Bush sin andre periode gjennomførte Putin en kort militær sommeroffensiv i Georgia, noe som skapte en isfront mellom de to lederne. Konflikten vakte opp traumer fra den kalde krigen og var samtidig et frampek mot Putins tiltagende konfronterende opprustnings- og intervensjonslinje.

På samme måte tinte kaldkrigsfronten opp med Obama i presidentstolen. Nå skulle USA og Russland trykke på «reset-knappen» i det bilaterale forholdet. Igjen ble tøværet av midlertidig karakter. Annekteringen av Krim og Russlands resolutte og avgjørende militære involvering i borgerkrigen i Syria demonstrerer at forholdet skar seg, og at USAs lederrolle internasjonalt er falmende. Putin bestemmer, mens Obama protesterer. Som avskjedshilsen til Obama-administrasjonen hacket Putin demokratenes informasjonssystemer $\mathrm{i}$ et forsøk på å påvirke valget i demokratenes disfavør (Lipton, Sanger \& Shane 2016). Obama forsvinner, og det gjør kanskje også de økonomiske sanksjonene overfor Russland som Trump trolig ikke ser poenget med.

\section{Norge - fired or hired?}

Norge har en ting som Trump verdsetter og forstår: hard valuta. Dette kan være en av de beste inngangsbillettene til å fremme bilaterale relasjoner med USA under Trump. Med solide statsfinanser har Norge råd til å oppnå NATOs $2 \%$ av BNP-krav til militære utgifter, slik NATO besluttet på toppmøtet i Wales. Med uforutsigbare Trump ved roret er Norge mer avhengig av europeiske alliertes forsvarsevne. Hvis Norge vil bli Trumps partner i å løfte europeisk forsvarsinvesteringer opp mot det vedtatte nivået, vil vi kunne sikre gode bilaterale forbindelser i realiseringen av en sterk felles interesse: økt europeisk forsvarsevne. Trump forstår foreløpig verdenspolitikken primært i økonomiske termer, i dollar og cent. Handel og arbeidsplasser i USA er viktigst. Sikkerhetspolitikken kommer tidvis i bakgrunnen.

Trump fremstår som en dominant bilateralist som vil trigge en sammensmelting av handel og sikkerhet. Alt tyder på at han ønsker å dominere andre stater og få full uttelling for sin maktbase gjennom bilateral dominans. Dette foretrekkes fremfor å la

\footnotetext{
${ }^{7}$ Crouching Tiger: What China's Militarism Means for the World (2015); Death by China: Confronting the Dragon (2011); The Coming China Wars: Where They Will Be Fought and How They Can Be Won (2007).
} 
seg binde opp av avtaleverk og multilaterale institusjoner. Trumps intimiderende framferd overfor andre stater minner om russisk tvangsdiplomati i den postsovjetiske sfæren. Kanskje den liberale verdensorden vi har tatt for gitt vil bli erstattet av to dominante bilaterale tvillingers beinharde maktpolitikk? En i Kreml og en i det ovale kontor.

Hvor står vi og hvor går vi i forholdet til USA? Er vi uavhengige eller underdanige? Kanskje Norge best beskrives som et proaktivt haleheng? Vi er ikke uunnværlige for USA, men vi har noe å tilby som USA verdsetter, både innen etterretning, fredsdiplomati og likvide midler. Så lenge vi bidrar på de aller viktigste sikkerhetspolitiske frontene for USA så glattes de mindre krusningene over av begge parter. Militære bidrag i Afghanistan og Libya har gitt oss status som en pålitelig alliert, og etterretningssamarbeidet verdsettes sterkt i Pentagon og ved CIAs Langley-hovedkvarter.

Motreaksjoner kan imidlertid komme under Trump. En bilateral rift med Trump-administrasjonen kommer nok før eller siden. Forhåndslagret materiell og jevnt stasjonert personell fra US Marines i Trøndelag er noe av det som kan tenkes trukket tilbake dersom det tilspisser seg mellom Trump og Norge. Men selv under en slik rift vil trolig relativt gode forbindelser til CIA og Pentagon kunne opprettholdes, selv om presidenten skulle være uinteressert. Administrasjoner kommer og går, men verdens største byråkrati består.

Utenriksminister Børge Brendes uttalelser i disfavør av Trump sommeren 2016 har nok blitt notert i Trumpleiren. Det teller heller ikke positivt at Statsminister Solberg etter valget kom sent i rekken av gratulasjoner per telefon. Vårt kanskje sikreste inntak til innflytelse i Washington, etterretningssiden, ser ut til å bli et usikkert kort ettersom Trump har misbilliget hele USAs etterretningssystem i perioden før innsettelsen. Trumps selvsentrerte sjarmoffensiv ved CIAs hovedkvarter rett etter innsettelsen bøter nok lite på tillitskrisen han selv har skapt. Dette er foruroligende for Norge med vår rolle som NATOs fremskutte etterretningstunge nordflanke.

Vil vi motvillig la oss diktere av Trump og USAs ønsker og krav i tiden fremover? Eller vil et konstruktivt forhold videreføre tiår med nære og fortrolige forbindelser? Uenigheter vil alltid komme, men de kan bli vanskeligere å håndtere med Trump ved roret. Dersom vi anses som illojale eller unødvendig konfronterende vil sannsynligvis mottiltakene bli markante og merkbare. Fired or hired, slik er Trumps stil, noe Obamas avtroppende justisminister fikk merke da hun ikke ville rettslig forsvare Trumps midlertidige innreiseforbud. Trump gir ikke ved dørene. Han tar snarere kollekt ved dørene før du slipper ut. Denne mentaliteten kan antas å ha implikasjoner for nivåene på USAs bistand og utviklingshjelp under Trump også.

Trump bedriver foreløpig politikk, både nasjonalt og internasjonalt, som om motkrefter ikke finnes. Motkreftene vil gjøre seg gjeldene og hva vil skje når Trump føler seg ydmyket internasjonalt? Alt tyder på at han da vil lange ut og slå tilbake så hardt som mulig. Hva som skjer etter at Trump har levert sin 'counter-punch'? Ja, det knytter det seg enorm usikkerhet til. Selv om det er henrivende å leve i spennende tider, så har nok Stephen Walt (2017) rett når han påpeker at «We are in for a very bumpy ride to an unknown destination». 


\section{Anders G. Romarheim}

\section{Litteratur}

Beasley, Vanessa B. (2004) You, the People: American National Identity in Presidential Rhetoric, College Station: Texas A \& M University Press.

Beckett, Lois \& Ben Jacobs (2016) 'Donald Trump endorsed by NRA despite history of gun control support' The Guardian, 21.05.

Davidson, Adam (2016) 'Trump's muse on U.S. trade with China', The New Yorker, 12.10.

Jervis, Robert (2017) 'President Trump and IR theory', H-Diplo ISSF Policy Series, 02.01. Tilgjengelig fra: https://issforum.org/roundtables/policy/1-5b-jervis

Leira, Halvard et al. (2007) Norske selvbilder og norsk utenrikspolitikk. Oslo: Norsk Utenrikspolitisk Institutt.

Lipton, Eric, David E. Sanger \& Scott Shane (2016) 'The Perfect Weapon: How Russian Cyberpower Invaded the U.S.', The New York Times, 13.12.

Mead, Walter Rusell (2017) 'The Jacksonian Revolt: American Populism and the Liberal Order', ForeignAffairs.com, 20.01.

Mead, Walter Rusell (2003) Special Providence, New York: Alfred A. Knopf.

Navarro, Peter (2007) The Coming China Wars: Where They Will Be Fought and How They Can Be Won, Upper Saddle River, N.J.: Financial Times Press.

Navarro, Peter og Greg Autry (2011) Death by China: Confronting the Dragon, Upper Saddle River, N.J.: Prentice Hall.

Navarro, Peter \& Gordon C. Chang. (2015) Crouching Tiger: What China's Militarism Means for the World, New York: Prometheus Books.

Restad, Hilde (2014) American Exceptionalism: An idea that made a nation and remade the world. New York: Routledge.

Trump, Donald J. med Tony Schwartz (1987) The Art of the Deal, New York: Ballantine Books.

Tvedt, Terje (2009) Utviklingshelp, utenrikspolitikk og makt: Den norske modellen. 2. Utg. Oslo: Gyldendal Akademisk.

Walt, Stephen (2017) 'America's new president is not a rational actor', ForeignPolicy.com, 25.01. Tilgjengelig fra http://foreignpolicy.com/2017/01/25/americas-new-president-is-not-a-rational-actor/

Wendt, Alexander (1992) 'Anarchy is what States Make of it: The Social Construction of Power Politics', International Organization, Vol. 46, No. 2 (Spring, 1992).

\section{Om forfatteren}

Anders G. Romarheim er førsteamanuensis ved Institutt for forsvarsstudier. Han har hovedfag i statsvitenskap fra Universitetet i Oslo, og en doktorgrad i War Studies fra King's college, London. Han har vært tilknyttet Institutt for forsvarsstudier siden 2006, kun avbrutt av et engasjement i Sikkerhetsutvalgets sekretariat for å utrede ny Sikkerhetslov. Forut for 2006 arbeidet han ved Norsk utenrikspolitisk institutt. Romarheim vil takke IP-redaksjonen, og dens oppnevnte gjennomlesere, for solide og nyttige kommentarer i arbeidet med denne artikkelen. Korrespondanse: aromarheim@ifs.mil.no. 